\title{
O IPTU COMO INSTRUMENTO DE INTERVENÇÃO NO USO E OCUPAÇÃO DO SOLO URBANO CONFORME DISPOSIÇÕES DO ESTATUTO DA CIDADE
}

Maria de Fátima Ribeiro*

SUMÂRIO: 1. Introdução. 2. Parcelamento, Edificação ou Utilização Compulsórios dispostos no Estatuto da Cidade. 3. $O$ IPTU como instrumento de intervenção no uso e ocupação do solo urbano. 4. O Estatuto da Cidade e a progressividade do IPTU. 5. Progressividade Temporal do IPTU. 6. A função social da Propriedade na Constituição Federal: Considerações sobre o IPTU. 7. Progressividade extrafiscal. 8. A Emenda Constitucional $29 / 00$ e as alterações do art. 156 da Constituição Federal. 9. A Progressividade como penalização imposta ao proprietário do imóvel por força do artigo 182 da Constituição Federal. 10. IPTU e o Plano Diretor. 11. Conclusão. 12. Bibliografra.

SUMMARY: 1. Introduction. 2. Installments, Building or Arranged Compulsory Utilization in the Statute of the City. 3. The IPTU as instrument of intervention in the use and occupation of urban soil. 4. The Statute from the City and the IPTU. 5. Progressive Time of the IPTU. 6. The social function of the Estate in the Federal Constitution: Considerations about the IPTU. 7. Extrafiscal Progressive. 8. The Constitutional Amend 29/00 and the Alterations of the Article 156 of the Federal Constitution. 9. The Progressive as sanction imposed to owner because of the Article 182 of the Federal Constitution. 10. IPTU and the Director Plan. 11. Conclusion. 4. Bibliography. 
SUMARIO: 1. Introducción. 2. Los Parcelamentos, Edificación o la Utilización Obligatoria Arreglada en el Estatuto de la Ciudad. 3. El IPTU como Instrumento de la Intervención en el Uso y la Ocupación de Tierra Urbana. 4. El Estatuto de la Ciudad y el IPTU. 5. El Progresividad Temporal del IPTU. 6. La Función Social de la Propiedad en la Constitución Federal: las Consideraciones acerca del IPTU. 7. Progresividad Extrafiscal. 8. El Enmienda Constitucional 29/00 y las Modificaciones del Artículo 156 de la Constitución Federal. 9. La Progresividad como Sanción impuesta al Dueño por Causa del Artículo 182 de la Constitución Federal. 10. IPTU y el Plano Director. 11 Conclusión. 12. Bibliografia.

RESUMO: O Estatuto da Cidade regula o suo da propriedade urbana, dispondo sobre as penalidades decorrentes de não atendimento ao plano diretor. O imposto progressivo existe para atender o crescimento da sociedade, impondo um comportamento especifico. Toda propriedade imobiliária urbana deve cumprix sua função social, sob pena de aumento tributário progressivo e até a desapropriação.

ABSTRACT: The statute of the city regulates the use of urban property arranging, on the penalties for not attending the principal plane. Progressive taxes exist to attend the growth of society, which also imposes a specific behavior. Every urban property must keep its social means or else the consequences are taxes rise and expropriation.

RESUMEN: El Estatuto de la Ciudad regula el uso de la propiedad urbano, en las multas por no asistir al plano principal. Los impuestos progresivos existen para asistir al crecimiento de la sociedad, que también impone una conducta especifica se supone que toda la propiedad urbana debe lograr con su función social bajo la multa aumentar en los impuestos progresivos $y$ hasta su desapropiación

PALAVRAS-CHAVES: Estatuto da Cidade. Função social da propriedade. Extrafiscalidade. Progressividade. 
KEY WORDS: Statute of the city. Social Mean of Property. Supervising. Progressive.

PALABRAS-LLAVES: El Estatuto de la Ciudad. Función social de la propiedad. Impuesto progresivo sobre la propiedad.

\section{Introdução}

Os governos municipais sempre tiveram dificuldades de controlar e orientar o uso, o desenvolvimento e a expansão das cidades. Após mais de dez anos de tramitação no Congresso Nacional, foi aprovado o Estatuto da Cidade, que regulamenta os artigos 182 e 183 da Constituição Federal de 1988.

Assim, em 10 de julho de 2001 foi sancionada a Lei $n^{2} 10.257$, instituindo o Estatuto da Cidade. Esta legislação estabelece normas que regulam o uso da propriedade urbana, visando a uma melhor execução da política urbana, melhoria da segurança, do bem-estar das pessoas e do equilíbrio ambiental. Com ele, os municípios dispõem de um marco regulatório para a política urbana, que pode levar a importantes avanços.

$\mathrm{O}$ inciso II do artigo 2 , institui a gestão democrática através da participação da população e de associações representativas dos vários segmentos da comunidade na formulação, execução e acompanhamento de planos, programas e projetos de desenvolvimento urbano.

O Estatuto da Cidade dá respaldo constitucional a uma nova maneira de realizar o planejamento urbano. Sua função é garantir o cumprimento da função social da cidade e da propriedade urbana, o que significa o estabelecimento de normas de ordem pública e interesse social que regulam o uso da propriedade urbana em prol do bem coletivo, da segurança e do bem-estar dos munícipes.

Com o propósito de maiores receitas, os municipios tem aumentado expressivamente as alíquotas do IPTU - Imposto sobre a Propriedade Predial e Territorial Urbana, e, ao mesmo tempo diversas ações judiciais são interpostas no sentido de limitar a tributação deste imposto, por parte dos municípios.

Depois de alguns anos de debates legislativos e ações políticas para atender as expectativas dos contribuintes do IPTU, bem como dos municípios, foi aprovada a Emenda Constitucional $\mathrm{n}^{\mathrm{a}} 29$ de 13 de setembro de 2000, que deu nova redação ao parágrafo primeiro do artigo 156 da Constituição Federal. Assim, referida Emenda possibilitou ao 
município, tributar a propriedade predial e territorial urbana, podendo arrecadar conforme a capacidade contributiva de cada contribuinte, bern como utilizar o IPTU de forma extra-fiscal, face à ocupação e utilização do solo, previsto no Plano Diretor do Município.

O Estatuto da Cidade veio para atender o princípio constitucional pelo qual a propriedade privada deve atender a sua função social, gerando obrigações de direito real e obrigacional entre as partes envolvidas. Assim, através desta nova lei, foram criados os seguintes institutos: parcelamento, edificação ou utilização compulsórios; o IPTU progressivo; o direito de superfície; o direito de preempeção; as operações urbanas consorciadas e o consórcio imobiliário.

\section{Parcelamento, Edificação ou Utilização Compulsórios dis- postos no Estatuto da Cidade}

O Artigo $5^{\text {a }}$ do Estatuto da Cidade dispóe sobre o parcelamento, edificação ou utilização compulsórios do solo urbano não edificado, subutilizado ou não utilizado, conforme dispõe: Lei municipal específica para área incluída no Plano Diretor poderá determinar o parcelamento, a edificação ou a utilização compulsórios do solo urbano não edificado, subutilizado ou não utilizado, devendo fixar as condiçóes e os prazos para a implementaçấo da referida obrigação. ${ }^{1}$ Tal dispositivo tem por finalidade coibir a utilização inadequada da propriedade urbana, fazendo com que o proprietário de um imóvel não edificado, subutilizado ou não utilizado promova sua utilização, de acordo com os princípios constitucionais que norteiam o direito de propriedade, previstos nos artigos 182 e 183 da Constituição Federal e no artigo $2^{a}$ do Estatuto da Cidade. Para a efetivação destas orientações, necessário se faz a instituição de lei municipal a respeito.

$\mathrm{Na}$ Constituição Federal, no artigo 5a , são destacadas três referencias diretas à propriedade: a inviolabilidade do direito à propriedade; garantia do direito de propriedade e a qualificação que toda propriedade atenderá sua função social. (art. 5a , caput, XXII e XXIII)

Da mesma forma a propriedade vem destacada no $\S 2^{a}$ do art. 182 a

- O parágrafo segundo do referido artigo destaca que o proprietário será notificado pelo Poder Executivo municipal para o cumprimento da obrigação, devendo a notificação ser averbada no Cartório de Registro de Imóveis. 
propriedade urbana atenderá sua função social quando atender às exigências fundamentais de ordenação da cidade expressas no plano diretor: Esse dispositivo encontra-se no capítulo II da ordem econômica, onde a propriedade urbana também é informada pelos princípios gerais da atividade econômica. Nos incisos do art. 170, encontram-se disposiçôes sobre a propriedade privada, a função social da propriedade e a defesa do meio ambiente.

Nesse sentido, a Constituição destaca em seu art. 174 que o planejamento é obrigatório para o Estado e indicativo para o setor privado, tendo o art. 182 definido que o instrumento de planejamento das cidades, é o plano diretor que passa a ser o instrumento básico da política de desenvolvimento e expansão urbana, sendo que a cooperação das associações representativas no planejamento municipal segundo art. 29, XII, é obrigatória.

\section{O IPTU como instrumento de intervença no uso e ocupa- ção do solo urbano}

O Estatuto da Cidade regulamenta dispositivos que procuram combater a especulação imobiliária nas cidades, conforme já apontado. A partir da vigência do plano diretor do município, áreas consideradas não utilizadas ou subutilizadas, situadas em regiões dotadas de infra-estrutura estão sujeitas à edificação e parcelamento compulsórios (artigos $5^{\underline{a}}$ e $6^{a}$ ).

O município tem o poder de determinar os critérios para indicação das terras que considera ociosas ou subutilizadas, e poderá estabelecer prazos e condições para induzir o aproveitamento dos terrenos pelos proprietários - no mínimo um ano para a entrada de um projeto no órgão competente, e dois anos a partir de sua aprovação para a efetiva edificação.

No caso do não-cumprimento dos prazos ou condições da edificação ou utilização compulsória, o Município poderá aplicar sobre esses terrenos o instrumento do IPTU progressivo no tempo (artigo $7^{a}$ ).

Esse instrumento consiste no aumento progressivo da alíquota de imposto sobre a propriedade predial e territorial, por até cinco anos consecutivos. A alíquota do IPTU poderá dobrar de ano a ano, podendo atingir um máximo de quinze por cento do valor venal do imóvel.

Se o proprietário ainda assim não realizar o aproveitamento do terreno, a cobrança poderá permanecer na alíquota máxima. Se após cinco anos de cobrança do IPTU progressivo o proprietário não tiver 
cumprido a obrigação de parcelamento, edificação ou utilização, o Município poderá desapropriar o imóvel pelo valor venal do IPTU, pagando ao proprietário com títulos da dívida pública (artigo $8^{\mathrm{a}}$ ).

Esse conjunto de instrumentos - edificação compulsória, IPTU progressivo e desapropriação com pagamento em títulos da dívida pública - pode representar uma possibilidade de intervir efetivamente no crescimento da cidade, promovendo uma ocupação mais intensa nas áreas e dessa maneira reduzindo a pressão pela urbanização das áreas da cidade.

\section{O Estatuto da Cidade e a progressividade do IPTU}

Se constatado que não houve o cumprimento das condições e prazos estabelecidos pela legislação municipal, para que o proprietário do imóvel, quando notificado para parcelar, edificar ou utilizar compulsoriamente o mesmo, estará sujcito à cobrança do IPTU progressivo no tempo, mediante o aumento da alíquota pelo prazo de cinco anos consecutivos, sujeitos, à desapropriação quando ultrapassado o prazo sem manifestação do proprietário (art. 182 - CF).

Nos termos do artigo 156, parágrafo primeiro, com a redação original da Constituição Federal de 1988, o IPTU podia ser progressivo, nos termos de lei municipal, de forma a assegurar o cumprimento da função social da propriedade. Com a redação da Emenda Constitucional $n^{\underline{a}} 29 / 00$, o parágrafo primeiro do artigo 156 , passou a vigorar com a seguinte redação: Sem prejuízo da progressividade no tempo a que se refere o art. 182, $\$ 4^{ \pm}$, inciso II, o imposto previsto no inciso I, poderá: $I$ - ser progressivo em razão do valor do imóvel; e II - Ter alíquotas diferentes de acordo com a localização e o uso do imóvel.

A função social da propriedade já vem estatuída no artigo $5^{\underline{a}}$ da Constituição Federal ao destacar que a propriedade deverá atender os dispositivos constitucionais e infraconstitucionais.

A progressividade do IPTU está relacionada com o princípio da capacidade contributiva, vez que grava com maior ônus aquele que detém maior riqueza, atribuindo pessoalidade ao foco tributante, levando em consideração além dos elementos de incidência também a condição econômica do contribuinte. ${ }^{2}$

2 - Cf. A Nora Progressividade do IPTU na Emenda Constitucional $\pi^{2}$ 29/00, de Manolo Del Olmo, http:/ www direitonaweb.adv.br ano I, $1^{\text {to }}$ ed, de 23/07/02. 
Essa previsão constitucional genérica possibilita ao município a instituição de IPTU progressivo, em função da capacidade econômica do contribuinte, com a finalidade de aumentar a receita tributária, dentro do salutar princípio da isonomia jurídica (arts. 5- e 150, II, da CF), no sentido de justiça tributária. Essa tributação progressiva, só pode se ater à modalidade fundada no valor venal do imóvel, sendo descabíveis as demais modalidades.

É que somente o valor venal do imóvel espelha, objetivamente, a capacidade contributiva de seu proprietário, que outra coisa não é senão o critério da valoração do princípio da isonomia, na afirmativa Hugo de Brito Machado. ${ }^{3}$

\section{Progressividade Temporal do IPTU}

A progressividade dos tributos está relacionada com justiça tributária e com a capacidade contributiva. Mizabel Derzi e Sacha Calmon Navarro Coelho ensino que por progressividade entende-se a majoração da alíquota à medida que cresce o valor da matéria tributável. Não é incompatível com o princípio da igualdade e da proporcionalidade.

Com a progressividade realiza-se o princípio da justiça fiscal, na medida em que o tributo seja maior para quem dispõe de maior parcela da renda. Os impostos, assim, obedecem o princípio da capacidade contributiva (art. 145, parágrafo primeiro da Constituição Federal). A progressividade no IPTU, além do atendimento ao princípio da capacidade contributiva, assegura o cumprimento da função social da propriedade.

Com a modificação do texto constitucional (Emenda Constitucional $\mathrm{n}^{\mathrm{a}}$ 29/00), fica facultado ao município a instituição do IPTU progressivo em razão do valor do imóvel, além de poder fixar alíquotas diferenciadas em razão da localização do imóvel.

$O$ sistema jurídico brasileiro oferece uma forma especial de progressividade, que é a progressividade no tempo, prevista no art. 182 da Constituição Federal. Tal progressividade tem por finalidade desestimular os proprietários de imóveis de os manterem contrariando os planos de urbanização das cidades. Esta progressividade não é um instrumento de justiça tributária. Trata-se de instrumento da política urbana.

O Artigo 182, parágrafo 4ª , inciso II da Constituição Federal dispõe 
que a política de desenvolvimento urbano, executada pelo Poder Público municipal, conforme diretrizes gerais fixadas em lei, tem por objetivo ordenar o pleno desenvolvimento das funções sociais da cidade e garantir o bem-estar de seus habitantes.

Desta forma, fica facultado ao Poder Público municipal, mediante lei específica para área incluída no plano diretor, exigir, nos termos da lei federal, do proprietário do solo urbano não edificado, subutilizado ou não utilizado, que promova o seu adequado aproveitamento, sob pena de sucessivamente ser provocar o parcelamento ou edificação compulsórios, da instituição do imposto sobre a propriedade predial e territorial urbana progressivo no tempo bem como da desapropriação com pagamentos de títulos da dívida pública, nas condições no referido artigo estabelecidas.

Roque Carrazza destaca que a respeito do IPTU, há uma questão pouco estudada, informando que nada impede que suas alíquotas aumentem progressivamente, à medida que o proprietário do imóvel urbano for perseverando em seu mau aproveitamento. Trata-se aí da progressividade no tempo, que não tem nada a ver com a progressividade fiscal, nem com a progressividade extrafiscal. ${ }^{5}$

Tal aumento pode redundar até na perda da propriedade. Tal situação deve ter embasamento em lei.

Para a progressividade no tempo se fazia necessária a instituição de lei federal. Daí, a partir de julho de 2001, o Estatuto da Cidade veio a colmatar esta lacuna legislativa (Lei $\mathrm{n}^{\underline{a}}$ 10.257).

\section{A função social da Propriedade na Constituição Federal: Considerações sobre o IPTU}

A teoria da função social da propriedade não tem mais a conotação do direito de propriedade com moldes romanos, absoluto, o que se percebe com o argumento do poder outorgado para seu exercício e utilização social, considerado como uma função não individual, e sim social.

Efetivamente, afirma-se que o proprietário tem o dever de exercer o direito de propriedade de acordo com os interesses da coletividade, cabendo-lhe apenas direcionar-lhe o exercício acordo as orientações da política social do município.

Sob o ponto de vista moderno, a função social da propriedade é tido como fórmula de conciliação do individual e do social, constituindo elemento inerente ao direito de propriedade.

- CARRAZZA, Roque Antonio. IPTU: ainda a questão da progressividade, in www.damasio.com.br, junho de 1997, capturado em 30 de julho de 2002. 
Portanto, este poder não é uma faculdade e sim um instrumento para realização da obrigação que lhe é imposta.

Por esta concepção, o direito de usar, gozar, dispor e reivindicar a propriedade, direitos concedidos ao proprietário, possuem como objetivo dar ao proprietário instrumentos para cumprir a função social da mesma.

Hugo de Brito Machado do discorrer sobre a progressividade do IPTU, ressalta que do ponto de vista da política urbana, pode-se entender que a propriedade cumpre sua função social quando atender às exigências fundamentais da urbanização, expressas no Plano Diretor. Isto, no entanto, segundo o tributarista, não significa que não existam outras formas pelas quais a propriedade também tenha que cumprir sua função social, até porque a propriedade há que ser encarada como riqueza que é, e não apenas como elemento a ser tratado pelas normas de política urbana. ${ }^{67}$

Nessa mesma trilha José Souto Maior Borges, destaca que a função social não é a de um atributo ou apêndice, que possa vir ou não a agregar-se ao domínio. A Constituição Federal não prevê alternativas para o exercício do direito de propriedade: com ou sem função social. Propriedade só com função social. A propriedade deverá portanto exercer -sempre-função social. Dito noutros termos: nenhuma propriedade sem função social. ${ }^{8}$

Os ensinamentos de Marco Aurélio Greco, asseveram que a Constituição de 1988 é pródiga em dispositivos que se referem à propriedade e à sua função social. No próprio art. $5^{\mathrm{a}}$, que consagra os direitos e garantias individuais, encontra-se o inc. XXII que garante o direito, enquanto o inc. XXIII prevê que a propriedade atenderá a sua função social. A referência à função socia,l surge ainda, no art. 156, parágrafo $1^{\underline{a}}$, no art. 170 , no art. 182, no art. 184 da mesma Carta Política. ${ }^{9}$

E esclarece, ainda que examinando os vários dispositivos, o primeiro comentário a fazer é o de que a palavra - propriedade - é utilizada em dois sentidos absolutamente distintos. Numa primeira acepção, a propriedade quer dizer vínculo existente entre o homem e um certo bem, que lhe permite uma série de condutas perante o objeto ou terceiros. Propriedade, neste sentido, se assemelha à noção de direito de propriedade, como estabelece o art. 5ª XXII. A segunda posição sobre a expressão - propriedade - é a do próprio bem que vem a ser objeto de certas condutas humanas. ${ }^{10}$

\footnotetext{
- MACHADO, Hugo de Brito. Curso de Direito Tributário. $12^{\circ}$ ed., São Paulo, Malheiros, 1997.

- A necessidade de que a propriedade cumpra sua função social, de há muito defendida por parte da doutrina, ganhou, no Brasil, status constitucional com a carta de 1934 , mediante a qual Getúlio Vargas implantou Estado Noro.

8 - BORGES, José Souto Maior. IPTU: progressividade. Revista de Direito Tributário, São Paulo, 12. 59, 1994, p. 77. 9 - GRECO, Marco Aurélio. IPTU-Progressividade - Função Social da Propriedade. Revista de Direito Tributário, $\mathrm{n}^{\mathrm{a}}$ 52, pg. 113.

10 - Id. Ibidem, p. 113.
} 
O que possui uma função social é, sem dúvida, a propriedade enquanto bem imóvel (sem prejuizo das demais formas de propriedade). A Constituição Federal, indica que estes objetos devem ser direcionados num certo sentido. Preocupa-se, então, o art. 156, parágrafo $1^{a}$, em indicar uma diretriz a ser atendida no uso concreto a que será submetido o bem, dentro das diversas condutas permitidas. A Constituição, nesse dispositivo, está prestigiando certos efeitos decorrentes da conduta concreta que poderá reportar-se ao bem, considerando os efeitos que melhor adequarem o imóvel ao contexto social em que se encontra, cumprindo, dessa forma, a sua função social. Isto porque a função social de um bem não é algo abstrato e hipoteticamente aferível, em está sujeito a padrões indeterminado e genéricos, mas, ao revés, só é perceptível no caso concreto, em razão das peculiaridades de cada situação, variando, portanto, de local para local."

No caso da progressividade do IPTU, a situação foi alterada pela Emenda Constitucional $n^{\hat{a}} 29 / 00$. Preceitua a Constituição, que a propriedade deve cumprir sua função social.

O fim social da propriedade é estatuído diversas vezes na Constituição Federal, ${ }^{12}$ tutelando o direito de propriedade, com as demonstrações do interesse coletivo de planejamento urbano, atingindo o respectivo fim social.

A Emenda Constitucional $n^{\mathrm{a}} 29 / 00$ exclui a condição de progressividade condicionada ao estrito cumprimento da função social da propriedade privada. Com a referida emenda, o IPTU poderá ter um caráter de progressividade fiscal, deixando de prevalecer a exigência de que o IPTU poderia ser progressivo, somente para atender a função social da propriedade privada. Assim, o município, por força desta Emenda e de lei municipal específica, poderá fixar alíquotas progressivas na medida do valor dos imóveis. É possível ainda, estabelecer alíquotas diferenciadas em razão da localização do imóvel e do seu uso, podendo assim estimular ou desestimular a ocupação de uma ou outra área da cidade.

Desta forma as alterações procedidas no artigo 156 da Carta Magna possibilitou a efetivação do princípio constitucional da função social da propriedade privada, estatuída no artigo $5^{\text {a }}$ e no 182 , parágrafo segundo.

A progressividade do IPTU prevista no $\$ 4^{\text {a }}$. do art. 182 , é a progressividade específica para ordenamento das funçóes sociais da cidade, só podendo ser exercitada através da modalidade ali prevista: a progressividade no tempo. Já aquela referida no $\S 1^{\text {at }}$ do art. 156 é a progressividade genérica, podendo ser exercitada através de qualquer das modalidades nela contidas, para assegurar o cumprimento da função social da

Id. Ibidem, p. 113.

Destaca através das diretrizes urbanísticas, com disposiçōes sobre a propriedade nos artigos 5ㄹ, incisos XXII, XXII, XIV e 170, II e II da Constituiçăo Federal. 
propriedade, bem como para regular qualquer matéria que se insira no âmbito das atribuições do Município, como já era pacífico na doutrina e jurisprudência.

Positivamente, não há como condicionar o exercício da extrafiscalidade genérica $\left(\S 1 \stackrel{\text { a }}{*}\right.$ do art. 156) ao exercício da extrafiscalidade específica $\left(\S 4^{\stackrel{a}{a}}\right.$. do art. 182). ${ }^{13}$

Além do aspecto da progressividade no tempo merece destaque também rápida abordagem sobre a extrafiscalidade do tributo.

A extrafiscalidade consiste na utilização do tributo como instrumento de política financeira, ressaltada por José Acúrcio Cavaleiro de Macedo, como uma forma de controle da conjuntura econômica: Sem a intensa utilização extrafiscal das medidas financeiras, despojar-se-iam de eficácia as funçôes contemporâneas do Estado, que oferecem o tríplice aspecto compensativo, corretório e estabilizador, escopo somente conseguível pelo abandono do dogma da neutralidade. São, portanto, as finanças extrafiscais um dos aspectos de maior relevo e expressão do intervencionismo estatal. ${ }^{14}$

Destaca também que as Finanças neutras converteram-se em Finanças funcionais, e os fins puramente fiscais que inspiravam o manejo do instrumental financeiro nas Finanças tradicionais foram sobrepujados pelas finalidades extrafiscais, cujo domínio se impôs preponderantemente. Converteram-se, assim, os impostos, as despesas, o crédito, o orçamento, em instrumentos maleáveis e flexíveis nas mãos do governante, em atinência estreita aos objetivos por este perseguidos. A distribuição dos impostos veio a guardar postulados de solidariedade e de justiça social. ${ }^{15}$

$\mathrm{O}$ autor arremata que o elemento solidariedade social tornou-se imperativo e dominador, a justificar o poder de exação do Estado, expoente superior dessa solidariedade, do mesmo passo em que fundamenta solidamente a noção de capacidade contributiva e legitima a progressividade. Esta, em suas formas mais atrevidas e rudes, fêz-se rotina na legislação dos povos civilizados. ${ }^{16}$

A respeito, afirma Roque Antonio Carrazza que a extrafiscalidade é o emprego de instrumentos tributários para fins não-fiscais, mas ordinatórios (isto é, para condicionar comportamentos de virtuais contribuintes, e não, propriamente, para abastecer de dinheiro os cofres públicos). ${ }^{17}$

Em decorrência das normas constitucionais dos arts. $145, \S 1^{\circ}, 156 \S 1^{\circ} \mathrm{e}$ $182 \S \S 2^{\circ}$ e $4^{\circ}$, da Constituição Federal, o IPTU somente admite a extrafiscalidade, contudo, para garantir o cumprimento da função social da

\footnotetext{
13 - HARADA, Kyoshi. Sistema Tributário na Constitução de 1988 - Tributação Progressiva. São Paulo, Saraiva, 1991, págs. 233 e 234.

14 - Aspectos Extrafiscais das Finanças Modernas, 1.959 , tese para Concurso à Cátedra.

15 - Id. Ibidem.

16 - Id. Ibidem.

17 - CARRAZZA, Roque Antonio, Curso de Direito Constitucional Tributáno, 11" edição, São Paulo, Mallheiros, 1.998 , p. 475.
} 
propriedade urbana, conforme definida no art. $182, \S 2^{\circ}$ da Constituição Federal, e desde que observados os requisitos do $\S 4^{\circ}$ desse mesmo artigo. ${ }^{18}$

Manoel Gonçalves Ferreira Filho, tratando do art. 156 da Constituição Federal de 1.988, leciona: Este dispositivo tem que ser interpretado em consonância com o art. $182, \S 4^{\circ}, I I$, ou seja, a progressividade aqui prevista só pode ser a progressividade no tempo. Não pode ser exigida senão de área incluída no Plano Diretor do Município por lei específica, nos termos condicionados por lei federal. Somente poderá ser aplicada com o fito de levar o proprietário de solo urbano não edificado, subutilizado ou não utilizado, a dar a esse imóvel o seu adequado aproveitamento, segundo o plano referido. E não poderá ser adotada antes de ter sido infrutifera a determinação de parcelamento ou edificação compulsórios. ${ }^{19}$

IR - Serão transcritas allgumas jurisprudências sobre a progressividade do IPTU:

IPTU. PROGRESSIVDADE. No sistema tributánio nacional é o IPTU inequivocamente um imposto real. Sob o imperio da amal Constitução, não é admitida a progressividade fiscal do IPTU, quer com base exclusiryamente no seu art. $145 \$ 1^{\circ}$, porque este imposto tem caráter real que é incompativel com a progressividade decorrente da capacidade economica do contribuinte, quer con arrimo na conjugação desse dispositivo constitucional (genérico) com o att. $156 \$ 1^{\circ}$ (especifico). A interpretação sistemática da Constituição leva inequivocamente à conclusão de que o IPTU com finalidade extrafiscal a que alude o inciso II do $\$ 4^{\circ}$ do art. 182 é a explicaçäo especificada, inclusive com linaitação temporal, do IPTU com finalidade extrafiscal aludido no art $156, \S 1^{n}$. Portanto, é inconstitucional qualquer progressividade em se tratando de IPTU, que não atenda exclusivamente ao disposto no art. $156 \$ 1^{\circ}$, aplicado com as limitaçöes expressamente constantes dos $\$ \S 2^{\circ}$ e $4^{\circ}$ do art. 182 , ambos da Constituição Federal Recurso extraordinatio conhecido e provido, declarando-se inconstitucional o sub item 2.2 .3 do setor II da tabela III da Lei 5.461, de 22.12.89, do Muncípio de Belo Horizonte. Como imposto de natureza real que é, incidiado sobre a propriedade, o domínio util ou a posse de inóvel localizado na zona urbaria do Município (CTN art 32), o IPTU näo pode variar en razão da presumível capacidade contributiva do sujeito passivo (proprietário, titular do domínio útil ou possuidor); a única progressividade admitida pela $\mathrm{CF} / 88$ en relaça ao mencionado tributo é a extrafiscal, destinada a assegurar o cumprimento da função social da propriedade urbana, nos temos dos arts. $156 \S 1^{\circ}$ e $182 \S 4^{\circ}$, Il, da CF. Com base nesse entendimento, o tribunal, por maioria de votos, declarou a inconstitucionalidade de norma legal do Municipio de Belo Horizonte, que estabelecia a progressividade de alíquotas do IPTU (Lei 5.461/89), segundo o valor e a localização do imóvel. (Ac. Do Pleno do STF, RE n.153771/MG, Rel. Min. Moreira Alves, , 20.11.96, Informativo 5TF n. 54, apud A Constiturgio na Visão dos Tribunais, p.1.144 1.145)

87957 IMPOSTO PREDLAL E TERRITORIAL URBANO PROGRESSIVIDADE DAS ALÍQUOTAS. A única hipótese constitucional de progressividade das aliquotas de IPTU é a extrafiscal, destinada a assegurar o cumprimento da função social da propriedade. Jurisprudència predominante do Plenário. Recurso conhecido a provido. (STF- Ac unân.da 2" T., publ em 19.0299- RE 2038920SP- Rel. Min. Nelson Jobin- Luiz Alvaro Augusto Pinto X Município de Säo Paulo-Advs. Luiz Henrique Texeira Cotrim e Atessandra Gomes do Nascimento Silva) in Boletim Informativo Semanal de Jurisprudencia ADV/COAD no 24/99, p.369.

EMENTA: IYTU. Progressividade. Inconstitucionalidade. Esta Corte, ao finalizat o julganento do RE 153.771, firmou o entendimento de que a progressividade do IPTU, que é imposto de natureza teá em que não se pode levar em considexação a capacidade econômica do contribuinte, só é admissível, em face da Constituiço, para o fim extrafiscal de assegurar o cumprimento da funçäo social da propricdade (que vem definida no art. $182 \S 2^{\circ}$ da Carta Magna), obedecidos os requisitos previstos no $\$ 4^{\circ}$ desse artigo 182. Por outro lado, também o Plenatro deste Tribunal, to julgar o RE 194.036, entendeu incorstitucional a progressividade do IPTU como estabelecida na Lei 6.747, de 21.12.90, do Município de Santo André (SP), ou seja, mediante a concessão de isençöes parciais sobre a aliquota desse imposto sobre o valor venal do terreno e o da edificação, conforme os critérios que fxa. Recurso extraordinário conhecido e provido, dedarando-se a inconstitucionalidade dos artigos $2^{\circ}$, $3^{\circ} \mathrm{e} 4^{\circ}$ da lei 6.747 , de 21 de dezembro de 1.990, do Muncípio de Santo Andre (SP). (RE-204666/SP, Relator Ministro Moreira Aves, Publicação DJ data 17.04.98, pp. 00018. EMENT VOL 01906-05 pp. 01092).

"FERREIRA HLHO, Manoel Gonçalves. Comentátos a Constituça, vol 3 apud A Constituição na Visäo dos Tribunais, TRF 12 Regiäo-Gabinete da Revista, Ed. Saraiva, p. 1147 


\section{Com a Emenda Constitucional 29/00, abriu novamente a discussão} sobre a progressividade das alíquotas em função do valor venal do imóvel. Entendia boa parte da doutrina e da jurisprudência que a progressividade autorizada pelas normas constitucionais é a progressividade no tempo. ${ }^{20}$ Assim, afirmam que não há na Constituição dois tipos de progressividade do IPTU. Há apenas a que sirva para assegurar a função social do imóvel, nas hipóteses, através do regime e pelos instrumentos consagrados no art. 182 da Constituição Federal. ${ }^{21}$

27 - EMENTA: Recurso extraordinário. IPTU. Progressividade. Ao julgar o RE 204.827, o Plemário desta Corte declarou incidentemente a inconstitucionalidade do art. $7^{\circ}$ e seus incisos I e II da Lei Municipal $6.989 / 66$, com a redaçäo dada pela Lei $10.921 / 90$, do Município de Säo Paulo, por instituir alíquotas progressivas alusivas ao IPTU, em razão do valor do imóvel, com ofensa ao art. $182, \S 4^{\circ}$, $\mathrm{I}_{\text {, da }}$ Constituiça Federal, que limita a faculdade contida no art $156, \$ 1^{\circ}$, à observância do disposto em lei federal e à utilizaça do fator tempo para a graduação do tributo. No tocante a indice de correção monetária, configura-se ofensa indireta à Conștituição, o que não dá margem ao cabimento do recurso extraordinário. Recurso extraordinátio conhecido em parte e nela provido (RE 220932/SP, Rel. Min. Moreira Alves, $1^{2}$ Turma do STF, Rectes: Brenno Dias Baptista e outros e Recto: Município de São Raulo) 88471 - IMPOSTO PREDIAL E TERRITORIAL URBANO - PROGRESSTVDADE. O artigo 156 da CF, que versa sobre os impostos dos Municípios, está vinculado ao artigo 182, inserido no capítulo constitucional da política urbana, e restringe o caráter progressivo do IPTU à garantia do cumprimento da função social da propriedade, sendo inadmissivel a progressividade com base na capacidade econômica do contribuinte. A faculdade deferida ao Poder Publico Municipal para exigir o imposto progressivo sobre a propriedade territorial urbana depende de: a) lei especifica, municipal, para área incluida to plano diretor; b) consequentemente, plano diretor; ol le federal em cujos termos esteja a exigência tributária; e d) exigência anterior de parcéamento ou edificação compulsórios, tendo em vista

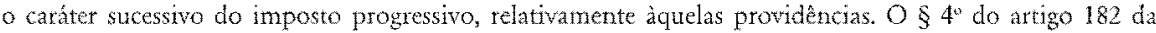
Constituiçăo permite ao Poder Público Municipal, mediante lei especifica para área inelúda no plano diretor, exigir, nos termos da lei federal, do proprietário do solo urbano não edificado, subutilizado ou não utilizado, que promova setu adequado aprovitamento, sob pena de vir a pagar imposto progressivo. A aliquota progressiva do imposto sobre a propriedade predial e territorial urbana, prevista no item $I 1$ do $\$ 4$ do artigo 182 da Lei Maior, se aplicará sucessivamente às exigências previstas no item I: parcelamento ou edificação compulsórios. A progressividade no tempo é condicionada à existência de lei federal que dispontha sobre o assunto. O comando constitucional não é dirigido, diretamente, ao Poder Público on ao Legislador do Município, mas o e, 3ndiretamente, por via de lei federal, que será necessária para se destinarem ao solo não edificado as exigências e as penalidades constitucionais (TJ-MGAc. Unần. da 4: Câm. Cív., de 11.02.99-Ap. 134.931/5-Rel. Des. Almeida MeloFazenda Pública X Construtora Tratex $\mathrm{S} / \mathrm{A}$ ) in. Boletim Informativo Semanal de Jurisprudência ADV/ COAD no. $30 / 99$, p. 465

23. Segue o voto do Min. MOREIRA ALVES, Relator do prineiro processo que tratou do assunto, e cujo pensamento vem sendo seguido, até hoje, no sentido de que o IPTU é um imposto real. Diz o Autor: Discordamos, data venia da fundanentaço de nossa Corte Suprema. Con eferto, não é por ser un imposto de natureza real que não se aplica o principio da capacidade comributiva ao IPTU. Aliás, a

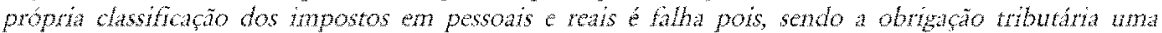
relaço juridica, é de sua essencia que haja um sujeito passivo, um sujeito arvo, un objeto e un vinculo de atributividade. Ora, sujeto passivo da obrgaçäo tributária sempre será a pesson - fistca on juridica - jamass o objto. Os impostos, portunto, sempre terão tatureza pessont. (CARLOS OCTAVIANO DE MEDEIROS MANGUEIRA, IPTU : Capacidade Contributiva, Progressividade, Função Social da Propredade e Vedaçäo a Confisco. A Visão do STF, data venia, artigos, novembro de 99 - httpi/f www dataveniainf.br/artigos/octaviano.html) 


\section{Progressividade extrafiscal}

A política de desenvolvimento urbano, executada pelo Poder Público Municipal, conforme diretrizes gerais fixadas em lei, tem por objetivo ordenar o pleno desenvolvimento das funções sociais da cidade e garantir o bem-estar de seus habitantes.

Dispõe o $\S 4^{a}$ do artigo 182 da Constituição Federal que é facultado ao Poder Público Municipal mediante lei específica para a área incluída no plano diretor, exigir nos termos da lei federal, do proprietário do solo urbano não edificado, subutilizado ou não utilizado, que promova seu adequado aproveitamento, sob pena, sucessivamente, instituir o Imposto sobre a progressividade predial e territorial urbana progressiva no tempo.

Por força deste dispositivo constitucional, o Município, através de lei própria, deverá instituir o plano diretor, regulando a função social da propriedade.

Com esse mecanismo o constituinte delineou a função social da propriedade, atendendo o plano diretor local, e propiciou a tributação progressiva, de natureza meramente extrafiscal.

A progressividade extrafiscal do IPTU garante $o$ atendimento da função social da propriedade, na medida em quem os interesses da sociedade se sobrepõem a interesses individuais, exigindo do proprietário a adequação do imóvel urbano com o plano diretor, podendo a alíquota do IPTU ser elevada de modo a melhorar o aproveitamento do terreno ou edificação.

O art. 156, I ressalta que compete aos Municípios instituir impostos sobre a propriedade predial e territorial urbana. $O \S 1^{\mathrm{a}}$ do mencionado artigo, por sua vez, salienta que o imposto previsto no inciso I poderá ser progressivo, nos termos de lei municipal, de forma a assegurar o cumprimento da função social da propriedade.

Esse dispositivo externa que a hipótese de incidência do IPTU é a propriedade de imóvel urbano. Ressalvando o direito de propriedade, e da vedação do confisco, ambos direitos assegurados pela Constituição Federal, existe a condicionante voltada para o atendimento da função social da propriedade.

Cabe aqui ressaltar que não obstante estar assegurado o direito de propriedade, esta cerceará o proprietário na sua limitação de uso, a fim de adequá-la aos contornos que a sociedade necessita, submetendo-se aos interesse sociais. Assim, a função social da propriedade é regulada pela 
aprovação do Plano Diretor do Município, obrigatório para aqueles com mais de 20.000 habitantes.

O advogado paulista Kiyoshi Harada adverte que cabe à lei municipal dizer quando, onde e como a propriedade urbana cumpre a sua função social, cujo conceito pode variar de um município para outro. A progressividade pode ser utilizada em quaisquer de suas modalidades, conquanto que vise o cumprimento da função social da propriedade urbana, segundo as prescrições da lei municipal. Ressalta-se que dentro do perímetro urbano de um único município, às vezes, um determinado imóvel pode ser considerado subutilizado, ou não, dependendo da zona de uso em que se situe. ${ }^{22}$

Com peculiar propriedade, Ruy Barbosa Nogueira destaca que o Estado pode, em benefício da coletividade, regular a atividade econômica, fazendo uso de seu poder de polícia para limitar o exercício da liberdades pelos particulares. Tal poder pode ser exercido, também, por meio da tributação, produzindo efeitos diversos, como fomentar uma determinada atividade ou restringi-la ,e até mesmo impedi-la, se ilícita. Por outro lado, o Estado também pode, em razão de seu poder de império, interferir nas relações econômicas cobrando tributos das pessoas que a ele se submetem, como forma de obter os recursos necessários ao desenvolvimento normal de suas atribuições. ${ }^{23}$

Aurélia Sampere Scarcioffolo, assegura que o imposto em sua função extrafiscal, vem sendo objeto de estudo desde o começo do século, acompanhando seus estudiosos as transformações por que vêm passando os sistemas políticos. Há uma crescente e constante intervenção do poder público em quase todos os setores da atividade dos particulares, principalmente na esfera econômica. O Estado passa a se utilizar dos impostos não apenas para cobertura de suas despesas de administração, mas também com finalidades de intervir na vida social, de exercer uma pressão sobre os cidadãos para orientar e organizar o desenvolvimento que pretende. ${ }^{24}$

A Constituição Federal de 1988 inovou, ao prever o uso da progressividade, no tocante ao IPTU, em duas situaçōes: a) em respeito ao princípio da capacidade contributiva, insculpido no art. 145 , parágrafo $1^{a}$, da Constituição

\footnotetext{
22 - HARADA, Kyioshi. A progressividade do IPTU. Cadernos de Direito Tributáno e Finanças Públicas, Săo Paulo, v. 1, n. 2, jan./mar. 1993, p. 119.

2. NOGUEIRA, Ruy Barbosa. Curso de Direto Tributário 9. ed. São Paulo: Saraiva, 1989, pg. 181/2. 24 - SCARCIOFFOLO, Aurélia Sampere. Imposto Predial e Teritorial Urbano. Revista de Direto Tributário, y. 51, pg, 222.
} 
e aplicável, sempre que possível, aos impostos; b) para conferir eficácia ao princípio da função social da propriedade, conforme determina o parágrafo $1^{\mathrm{a}}$ do art. 156, além do art. 182 , parágrafo $4^{\mathrm{a}}$, ambos relativamente ao IPTU. ${ }^{25}$

Assim, a progressividade do IPTU é então um instrumento constitucional da função social da propriedade imobiliária urbana. Isto porque a Constituição Federal, no art. 156, parágrafo 1 ${ }^{\text {a }}$, autoriza os Municípios, observadas as limitações constitucionais do poder de tributar (arts. 150 e 152), a instituir IPTU progressivo de forma a assegurar a função social da propriedade. No poder de tributar se inclui o poder de instituir as alíquotas do tributo - progressivas ou não. A previsão expressa, e não apenas implícita, de alíquotas progressivas deve a particular articulação e interrelação do IPTU com a função social da propriedade. E essa função, muito mais que a simples exigência técnica no art. 156, parágrafo $1^{\text {a }}$, corresponde a um princípio. Sendo a função social da propriedade um princípio, deverá ser assegurada sempre que compativel com a estrutura dos impostos. ${ }^{26}$

Ainda a respeito, Geraldo Ataliba, assegura que o art. 182 da Constituição Federal condiciona o uso do instrumento - progressividade no tempo - a observância de regras urbanísticas e outras, editadas pelo Município. Tal artigo prevê esta progressividade, como um tmeio de reforçar e sancionar a política urbana do Município, essencialmente traduzida no seu plano diretor. ${ }^{27}$

Quando o IPTU for utilizado com funções extrafiscais ele terá de obedecer ao disposto no parágrafo $1^{2}$ do art. 156 , em conjunto o com o art. 182, caso contrário sua eventual graduação deverá estar ligada a sua natureza fiscal, consagrada no parágrafo $1^{\frac{a}{2}}$ do art. 145.

No entanto, quando o IPTU for utilizado com o objetivo de participar do ordenamento, e do crescimento adequado da cidade, quando ele vise estimular e ordenar o desenvolvimento urbano, assegurando o equilíbrio na concentração das atividades; facilitando o uso e ocupação do solo evitando especulação imobiliária; ou mesmo quando disponha sobre a ocupação do solo e o gabarito das construções, ele estará sendo utilizado como componente da noção de uso em prol de função social da propriedade, sendo estatuído nos termos do art. 182 da Carta constitucional.

25 - LEONETI, Carlos Araújo. O IPTU e a Função Social da Propriedade. Revista Dialética de Direito Tributário, n. 37, p. 20 .

2o - BORGES, José Souto Maior. IPT U: progressividade. Revista de Direito Tributário, São Paulo, n. 59 , 1994 , p. $80 / 1$

7 - ATALIBA, Geraldo. INTU - Progressividade. Revista de Direito Publico, Săo Paulo, v. 23, n. 93, jan./ mar. 1991, p. 234. 
Seguindo esta trilha assegura Marco Aurélio Greco que mesmo que se diga que há dois tipos de propriedade, o próprio art. 156 parágrafo $1^{a}$, vincula a figura à função social e esta não tem duplo significado. Não se pode esquecer que o tributo é um instrumento para determinados objetivos (função arrecadatória ou não) ${ }^{28}$. A progressividade é para assegurar o cumprimento da função social da propriedade, ou seja, da coisa enquanto inserida num contexto.

Importante discussão na ordem do dia, está em se saber se os arts. 156, inc. I, parágrafo $1^{1}, \mathrm{e}$ 182, parágrafo $4^{\mathrm{a}}$, da Constituição Federal, tratam de hipóteses diversas, ou não. Ambos disciplinam a mesma matéria, a progressividade do IPTU. E essa progressividade, nos termos constitucionais, tem como finalidade assegurar o cumprimento da função social da propriedade, devendo obrigatoriamente atender ao art. $5^{\text {a }}$, inc. XXIII, da Carta Magna.

Dessa forma, o parágrafo 1 a do citado art. 156, da Constituição Federal, ao referir-se à progressividade das alíquotas do IPTU, nada mais fez do que frisar esta possibilidade em capítulo relativo ao Sistema Tributário Nacional, já que tal tema é disciplinado pelo mencionado art. 182, que se insere no capítulo da Política Urbana.

Nesse sentido, Aurélia Sampere Scarcioffolo ${ }^{29}$ elucida que a noção de função social da propriedade em uma de suas vertentes está ligada expressamente à tributação; o imposto aqui será utilizado por disposição constitucional expressa com fins extrafiscais, para atender às exigências fundamentais de ordenação da cidade constantes do plano diretor. A novidade está em condicionar de forma expressa tal utilização do imposto progressivo, reservando-se, ainda, imposto progressivo no tempo, único e exclusivamente para o disposto no inciso II do parágrafo $4^{a}$ do art. 182.

Dispõe o $\S 4^{a}$ do art. 182 da Constituição Federal que é facultado ao Poder Público municipal, mediante lei específica, para a área incluída no plano diretor, exigir, nos termos da lei federal, do proprietário do solo urbano não edificado, subutilizado ou não utilizado, que promova seu adequado aproveitamento, sob pena da incidencia dos incisos I, II e III.

Como ensina Souto Maior Borges, a área a ser incluída no plano diretor corresponde apenas à demarcação do âmbito territorial de validade das normas municipais respectivas. A lei federal não pode ampliar ou restringir esse âmbito de validade especial. Seria penetrar na esfera do

\footnotetext{
23 - GRECO, Marco Aurtlo. IPTU-Progressividade - Função Social da Proptiedade Revista de Direito Thibuting, $\mathrm{n}^{\text {in }} 52, \mathrm{p}, 119$.

29 - SCARGIOFFOLO, Aurelia Sampere Imposto Predial e Temitorial Urbano. Revișa de Direito Tributáio, \%. $51, \mathrm{pg} .224$.
} 
peculiar interesse do Município. Porque é da função social que se trata, não há que guardar o Município lei federal alguma para que a sua própria legalidade, e no que the incumbe, contemplando-a na ordenação do plano diretor ou outra lei municipal. ${ }^{30}$ Ainda esclarece o citado autor que se a lei federal de normas gerais, no seu âmbito de aplicabilidade, sobrevier ou anteceder a adoção dessas medidas, o Município há de compatibilizarse com ela. Deverá adaptar a sua legislação à regência da matéria na lei da Uniẫo. É este um caso excepcionalíssimo em que cabe, no direito brasileiro, a aplicação da regra: direito federal corta direito local..$^{31}$

Deve ser observado que a eventual inexistência da lei federal que dispõe o parágrafo $4^{\text {a }}$, do art 182 , da Constituição Federal, não inibia o Munić́pio de, com base em lei local, tomar as providências ali referidas, como fora exaustivamente aqui apresentado pelos doutrinadores pátrios. ${ }^{32}$

Ao comentar sobre a necessidade da elaboração de lei federal para o exercício da atividade legislativa municipal a respeito da progressividade do IPTU. Souto Maior Borges ensina que condicionar o exercício da lei municipal à preexistência de lei federal, implica a invalidação do princípio da autonomia municipal, inviabilizando a vinculação do IPTU à sua característica mais eminente, porque estará desvinculada da mera percepção de recursos financeiros, que é a de assegurar a função social da propriedade (art. 156, parágrafo $1^{a}$ ). ${ }^{33}$ Assim mostra-se que a progressividade do IPTU não deve servir de pretexto para obstaculizar o exercício da competência tributária municipal na sua plenitude.

\section{A Emenda Constitucional 29/00 e as alterações do art. 156 da Constituição Federal}

Com a redação constitucional e o enfoque destinado ao IPTU progressivo, antes da Emenda Constitucional $n^{ \pm} 29$, de 13/09/2000, para o município aplicar a progressividade do IPTU, seria necessário: Lei Federal regulando a progressividade; Plano Diretor do munićpio; Lei Municipal estabelecendo a progressividade do IPTU.

Os municípios se esforçaram para preencher os requisitos, fizeram um plano diretor e a lei municipal. Boa parte dos municípios que instituíram o IPTU, tiveram seus atos contestados em juízo. O Supremo Tribunal Federal, entendeu que a progressividade do IPTU não era

\footnotetext{
3) BORGES, José Souto Maior. IPJU: progressividade Revista de Direito Tributário, São Paulo, n. 59, 1994, p. 88. 3) Id. Ibidem, p. 88.

a CARRAZZA, Roque Antonio. Gurso de Direito Constitucional Tributajo, 3. ed. São Paulo: Revista dos Tribunais, 1991, p. 111

${ }^{3}$ BORGES, José Souto Maior. IPTU: progtessividade Revista de Direito Tribuánio, São Paulo, n. 59, 1994, p. 88.
} 
possível, pois os artigos constitucionais que a criaram não eram auto aplicáveis, dependiam de uma lei federal que viesse regulamenta-los.

Um dos argumentos seria que não haveria necessidade de lei federal, vez que esta teria como objetivo trazer a definição de função social da propriedade, segundo os mesmos nobres julgadores, a referida definição estaria presente no texto constitucional, apoiando este entendimento nos ensinamentos de José Afonso da Silva, ao destacar que é o imposto sobre propriedade predial e territorial urbana (art. 156,I), que representa o gravame fiscal da propriedade imóvel, com ou sem edificações, localizada na zona urbana ou com destinação urbana. Poderá ser progressivo nos termos da lei municipal, de forma a assegurar o cumprimento da função social da propriedade. A progressividade prevista no 156 é genérica e pode ser estabelecida com base em critérios diferentes do estabelecido no 182, parágra fo 4ª , que é vinculado a situação específica ali indicada, em que a aplicação da progressividade constitui sanção pelo não atendimento de regular e especifica exigência do Poder Público Municipal. ${ }^{34}$

Dalmo Dallari, escreve com propriedade, que esse esse critério da progressividade está previsto expressamente na Constituição Federal, no parágrafo primeiro, do artigo 156, como princípio de política fiscal, podendo ser aplicado sempre, seja qual for o uso que se dê a propriedade. Ele nada tem a ver com a progressividade prevista no capítulo da Constituição que trata da política urbana, pois esta tem o caráter de penalidade e só se aplica se não houver bom uso do imóvel. ${ }^{35}$

\section{A Progressividade como penalização imposta ao proprietário do imóvel por força do artigo 182 da Constituição Federal}

A progressividade temporal é destacadamente uma penalização imposta ao proprietário do imóvel urbano não edificado, subutilizado ou não utilizado, quando este negar-se a dar o adequado aproveitamento a seu imóvel, de acordo com as disposições estabelecidas no Plano Diretor do município.

Tal penalidade é aplicada por lei, após a imposição da penalidade de parcelamento ou edificação compulsória e, nos termos de lei federal. ${ }^{36}$

\footnotetext{
3t SILVA, José Afonso da. Curso de Direito Constimcional Prositivo, 6 ² ed. SP, RT, pág. 606

35 Folha de São Paulo, de $28 / 06 / 95$ - pág. 1-3.

36 Alguns autores entendian que no caso do IPU progressivo no tempo, sendo um tributo de competência municipal, não haveria por que let fedeal taçathe qualquer limite, estando pottanto o municipio apto a instituir referido imposto progressivo, através de aprovação de legislação específica emanada de seu Foder Legislativo.

Roque Antonio Carrazza ao dispor sobre a progressividade no tempo, salienta que a mesma é sancionatória e não tributária. Isso, deve ser feito exatamente para sancionar o proprietário do imóvel que renitir em não o ajustar às diretrizes do plano diretor. (IPTU - ainda a questão da progressividade, in www damasio.combr, junho/1997, p 6.
} 
Porém, o IPTU, quando progressivo, deve estar ligado ao cumprimento da função social da propriedade e consequentemente ao plano diretor municipal.

A Constituição Federal, 182, $\S 1$ a , ao dispor sobre o plano diretor, refere-se como sendo o instrumento básico da política de desenvolvimento e de expansão urbana.

A função social da propriedade é a obrigação que tem o proprietário de imóvel de atribuir a seu bem, a utilidade que favoreça a sociedade, de acordo com o estabelecido no Plano Diretor.

A doutrina tem demonstrado se há ou não diferença entre o IPTU progressivo tributo e outro sanção. Pode ser observado que o IPTU, poderá ser progressivo ou não, em sendo, visará constranger o proprietário de imóvel urbano não utilizado um subutilizado a atribuir a propriedade a sua função social.

Em que pese ser a competência para estabelecer regras quanto ao IPTU, do ente municipal, o diploma constitucional que lhe atribui a referida competência é o mesmo que estabelece a necessidade da referida lei para aplicabilidade do instituto.

O conflito de normas existe, mas estas, geram efeitos, impedindo a aplicação da progressividade.

A Emenda Constitucional 29 alterou o artigo 156, mas manteve a redação do 182, com a exigência da lei federal que regule a matéria.

Esta Emenda estabeleceu que o IPTU progressivo deverá se ater ao valor do imóvel e sua localização, mas não resolveu o problema.

O artigo 182, caput, permaneceu com a redação original. Assim, o referido artigo, continua exigindo uma lei federal para regular a progressividade. Essa lei trata-se do Estatuto da Cidade, promulgado em julho de 2001.

Em que pese muitas pessoas que desconhecem o que seja IPTU progressivo, achando que tratasse de um artifício adotado pelas municipalidades para tirar dinheiro dos contribuintes, ela, na verdade tem o caráter punitivo, como facilmente se observa na redação do artigo

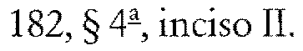

O próprio artigo utiliza-se da palavra pena, sendo que da leitura do referido artigo, pode-se extrair a conduta a ser punida, quase como um tipo penal.

Assim, aquele que deixar de dar ao imóvel urbano a destinação social, não utilizar ou subutilizar imóvel urbano não edificado, contrariando a política de crescimento urbano adotada pelo município, poderá incorrer 
nas penas que o artigo prelaciona e entre elas a progressividade do IPTU.

O legislador constitucional, mistura tributo com punição, fazendo com que alguns interpretes ressaltem tanto o caráter punitivo que ele possui.

O texto constitucional é claro ao estabelecer limites para a utilização da progressividade no IPTU, como forma de assegurar a função social da propriedade. Assim, poderá ser: a) sobre imóveis não edificados, subutilizados ou não utilizados; b) mediante lei específica para o imóvel; c) nos termos de lei federal; d) com prévia notificação do contribuinte; e) podendo promover o parcelamento ou edificação compulsórios; f) progressivo apenas do tempo. Dessa forma, ficaram definidos os limites para utilização do IPTU como instrumento de política urbana que visa assegurar o cumprimento da função social da propriedade urbana (função extrafiscal do imposto), através única e exclusivamente da progressividade prevista nos $\$ \S 2 .^{\text {a e }} 4 .^{\text {a }}$, e seu inciso II, do art. 182, todos da Constituição Federal, sendo esta a única possibilidade de diferenciação e graduação progressiva do IPTU.

Aires Fernandino Barreto, registra considerações: a respeito da progressividade do IPTU, ressaltando que esse imposto poderá ser progressivo, mas só de forma a assegurar o cumprimento da função social da propriedade, que, por sua vez, vem explicitada no art. $182 \mathrm{da}$ nova Constituição. Segundo esse dispositivo, a propriedade cumpre sua função social, quando atende às exigências fundamentais de ordenação da cidade expressas no plano diretor. De conseguinte, sempre que a propriedade imobiliária cumpre sua função social, não cabe qualquer progressividade. Progressão do IPTU, na nova Constituição, só é possivel nas hipóteses descritas no $\$ 4 .^{\text {a }}$ do art. $182 .^{37}$

Tem-se então, que o artigo 182 da Constituição Federal tem o seu enfoque voltado para a política urbana e não à tributação. Isto porque no conceito de tributo (artigo $3^{\mathrm{a}}$ do CTN) não se inclui prestação que se constitua sanção. Daí afirmar que nas situações dispostas no artigo 182 da Constituição, existirá uma sanção ontológica relativa e derivada do mau uso da propriedade para o que é prevista a progressividade no tempo. 


\section{IPTU e o Plano Dirctor}

Para aplicar os instrumentos urbanísticos previstos no Estatuto da Cidade, o Poder Executivo do município deverá obrigatoriamente ter o Plano Diretor. Referido plano ser aprovado pela Câmara Municipal. Tratase do instrumento básico da política de desenvolvimento e expansão urbana (artigos 39 a 42). O Plano Diretor é obrigatório para municípios com mais de 20 mil habitantes, e sua função principal é expressar os instrumentos por meio dos quais o município vai garantir o cumprimento da função social da cidade e da propriedade urbanas e garantir o atendimento às necessidades dos cidadãos quanto à qualidade de vida e justiça social.

O Plano Diretor deverá contar necessariamente com a participação da população e de associações representativas dos vários segmentos econômicos e sociais, não apenas durante o processo de elaboração e votação, mas, sobretudo, na implementação e gestão das suas diretrizes. Assim, mais do que um documento técnico, o Plano é um espaço de debate dos cidadãos e de definição de opções, conscientes e negociadas, por uma estratégia de intervenção no território. O Plano Diretor precisa ser revisto periodicamente, acompanhando o desenvolvimento da cidade, considerando suas características e peculiaridades.

É através do Plano Diretor que o municípios desenvolverão suas competências de promover, no que couber, adequado ordenamento territorial, mediante planejamento e controle do uso, do parcelamento e da ocupação do solo urbano.

O planejamento urbano não é realizado exclusivamente pelos municípios, devendo atender também às diretrizes gerais traçadas pela União e pelos Estados.

O Estatuto da Cidade, dispõe de elementos que aperfeiçoam a compreensão dos planos diretores, embasados em princípios de justiça orçamentária, participação popular e regulador de institutos jurídicos como o solo criado, o direito de preempcão, as operações urbanas, a transferência do direito de construir etc.

A finalidade do planejamento local é o adequado ordenamento do território municipal, com o objetivo de disciplinar o uso, o parcelamento e a ocupação do solo urbano (art. 30, VIII). O solo qualifica-se como urbano quando ordenado para cumprir destino urbanístico, especialmente. a edificabilidade e o assentamento viário. Esse ordenamento é função do 
plano diretor, aprovado pela Câmara Municipal, a que a Constituição Federal elevou à condição de instrumento básico da política de desenvolvimento e de expansão urbana (art. 182, § 1ª).

Assim, o plano diretor constitui o instrumento pelo qual se efetiva o processo de planejamento urbanístico local. Demonstra ser um instrumento potencializador da demanda por proteção ambiental, uma vez que normatiza a atuação estatal junto com a comunidade na ordenação de um meio ambiente urbano equilibrado e saudável promovendo a qualidade de vida no meio ambiente urbano.

Dispõe o $\S 4^{a}$ do art. 182 da Constituição Federal que é facultado ao Poder Público municipal, mediante lei específica, para a área incluída no plano diretor, exigir, nos termos da lei federal, do proprietário do solo urbano não edificado, subutilizado ou não utilizado, que promova seu adequado aproveitamento, sob pena da incidência dos incisos I, II e III.

\section{Conclusão}

Convém salientar que os legislativos municipais para que possam instituir as alterações procedidas tanto pela Emenda Constitucional 29/ 00 quanto pelo Estatuto da Cidade deverão aprovar lei para tanto, se atendo ainda ao princípio da anterioridade tributária.

O IPTU progressivo deve existir para ser um instrumento com a finalidade de atender ao crescimento ordenado da cidade, atendendo ainda aos aspectos sociais, para que todo imóvel urbano cumpra sua função social, criando assim, ordem no crescimento da cidade, melhorando as condições de vida da população.

A extrafiscalidade pode ser adotada por qualquer imposto, para estimular ou desestimular comportamentos, como no caso do IPTU. A Constituição Federal assegurando o direito de propriedade, cerceará o proprictário na sua limitação de uso, a fim de adequá-la aos objetivos sociais estabelecidos no Plano Diretor do município, considerando as delineações do Estatuto da Cidade.

Se o IPTU for utilizado com funções extrafiscais, terá de obedecer ao disposto no parágrafo $1^{a}$ do art. 156 em conjunto com o art. 182.

A progressividade no tempo do IPTU, é opcional aos municípios, no entanto para instituíla deverá aprovar e implementar o plano diretor, nos termos do Estatuto da Cidade, com a finalidade de atender a função social da propriedade. 
Referido Estatuto dispõe sobre as penalidades (sanções) que incidirão sobre o imóvel que não atender o disposto no plano diretor do município. Além da progressividade do IPTU no tempo, poderá o proprietário ter o seu imóvel desapropriado pela administração publica municipal, mediante o pagamento de títulos da dívida pública.

\section{BIBLIOGRAFIA}

ADOLFO, Luiz Gonzaga Silva. O estatuto da cidade e suas implicaçôes. In: Jus Navigandi, n. 51. [Internet] http://www1.jus.com.br/doutrina/ texto.asp?id=2200. Capturado 03.Ago.2002

ARANA, Jayme Gustavo. A progressividade do IPTU. In: Jus Navigandi, n. 53. http://www1.jus.com.br/doutrina/texto.asp?id=2485. Em 03.8.02.

ATALIBA, Geraldo. Hipótese de Incidência Tributária. 4. ed. São Paulo: Revista dos Tribunais, 1996.

ATALIBA, Geraldo. IPTU - Progressividade. Revista de Direito Público, São Paulo, v. 23, n. 93, jan./ mar. 1991.

ATALIBA, Geraldo. IPTU - Progressividade. Revista de Direito Tributário, n. 56 , jun. 1991.

BARBON, Sandra Aparecida Lopez. Do IPTU. Belo Horizonte. Del Rey, 1994.

BARRETO, Aires Fernandino. A progressividade nos impostos sobre a propriedade imobiliária. Revista de Direito Tributário, São Paulo, n. 4. BARRETO, Aires Fernandino. Imposto sobre a Propriedade Predial e Territorial Urbana. São Paulo: Bushatsky, 1976.

BARRETO, Aires Fernandino. Os Municípios na Nova Constituição Brasileira. In a Constituição Brasileira de 1988 - interpretações, Forense Universitária, SP, 1988.

BORGES, José Souto Maior. IPTU: progressividade. Revista de Direito Tributário, São Paulo, n. 59, 1994.

BOTALLO, Eduardo. Capacidade Contributiva. Revista de Direito Tributário, São Paulo, n. 47, p. 234-243, jan./mar. 1989.

CARRAZA, Elizabeth Nazar. Progressividade e IPTU. 1. ed. Curitiba:Juruá, 1998,

CARRAZA, Roque Antônio. Curso de Direito Constitucional Tributário, 11. ed. São Paulo: Revista dos Tribunais, 1998.

CARRAZZA, Roque Antonio. Curso de Direito Constitucional Tributário. $3^{\circ}$ ed., São Paulo, Revista dos Tribunais, 1991.

CARRAZZA, Roque Antonio. A progressividade na ordem tributária. 
Revista de Direito Tributário, São Paulo, n. 64.

CARRAZZA, Roque Antonio. IPTU: Ainda a questão da Progressividade. Capturado na internet em 20/07/02 http:/www.damasio.com.br/novo/ htm/artigos/art 43.htm

CARVALHO, Paulo de Barros. Teoria da Norma Tributária. São Paulo: Lael, 1981.

CONTI, José Maurício. Princípios Tributários da Capacidade Contributiva e da Progressividade. São Paulo: Dialética, 1996.

CORDEIRO, Diva Narcisa. IPTU - Progressividade. Revista de Direito Público, São Paulo, v. 24, n. 96, out./dez. 1990.

COSTA, Alcides Jorge. IPTU - Progressividade. Revista de Direito Público, São Paulo, v. 23, n. 93, jan./mar. 1991.

COTRIN, Luis Henrique T. A progressividade do IPTU na constituição de 1988. Revista Jurídica, Porto Alegre, v. 40, n. 179, set. 1992.

DEL OLMO, Manolo. A Nova Progressividade do IPTU na Emenda Constitucional $n^{\underline{a}} 29 / 00$, capturado em 13/07/02, http:// www.direitonaweb.adv.br/

DERZI, Misabel e Sacha Calmon Navarro Coelho. Imposto sobre a Propriedade Predial e Territorial Urbana, Saraiva, SP, 1982.

DIAS, Luiz Cláudio Portinho. IPTU - Sistema de Aliquotas Progressivas, função social da propriedade e a autonomia municipal, capturado na internet en 13/07/02 http://www.ambito-juridico.com.br/aj...

FERREIRA FILHO, Manoel Gonçalves. Comentários à Constituição, vol. 3, SP, Saraiva.

FURLAN, Valéria C. P. IPTU. 1. ed. São Paulo: Malheiros Editores, 1998, p. 164.

GARCIA, Plínio Gustavo Prado. IPTU: vedação constitucional a progressividade de alíquotas. Revista Dialética de Direito Tributário, São Paulo, n. 15, p. 66-71, dez. 1996.

GRECO, Marco Aurélio. IPTU- Progressividade - Função Social da Propriedade, Revista de Direito Tributário n. 52.

HARADA, Kyioshi. A progressividade do IPTU. Cadernos de Direito Tributário e Finanças Públicas, São Paulo, v. 1, n. 2, jan./mar. 1993.

HARADA, Kyioshi. Sistema Tributário na Constituição de 1988 Tributação Progressiva. SP, Saraiva, 1991.

LEFEBVRE, Henri. O direito à cidade, São Paulo: Ed. Documentos, 1969. LEONETTI, Carlos Araújo. O IPTU e a Função Social da Propriedade. Sintese, n. 21, 1998.

LEONETTI, Carlos Araújo. O IPTU e a Função Social da Propriedade. 
Revista Dialética de Direito Tributário, n. 37,OUT/1977.

MACEDO, José Acúrcio Cavaleiro. Aspectos Extrafiscais das Finanças Modernas, 1959, tese para concurso de cátedra.

MACHADO, Hugo de Brito. Ausência de Progressividade. Revista Dialética de Direito Tributário, n. 31.

MACHADO, Hugo de Brito. Curso de Direito Tributário, 12. ed., São Paulo: Malheiros, 1997.

MACHADO, Hugo de Brito. Os Princípios Jurídicos da Tributação na Constituição de 1988, $1^{\circ}$ ed., São Paulo: Revista dos Tribunais, 1989.

MANGUEIRA, Carlos Octaviano de Medeiros. Capacidade Contributiva. Progressividade, função social da propriedade e vedação de confisco. www.datavenia.inf.br/antigos/octaviano.html

MELO, José Eduardo Soares de. IPTU - A Função Social da propriedade e a Progressividade das Alíquotas, in Revista Dialética de Direito Tributário, $\mathrm{n}^{\mathrm{a}} 1$, págs. 41/56;

MORAES, Bernardo Ribeiro de. O IPTU e as Limitações do Legislador Municipal, in Repertório IOB de jurisprudência, $\mathrm{n}^{\mathrm{a}}$ 4/90, págs. 56/60.

NASCIMENTO, Carlos Valder do. A Questão da Progressividade do IPTU in Revista Tributária e de Finançcas Públicas, ano 8, na 34, setembro-outubro, 2000. RT, SP.

NÓBREGA, Airton Rocha Nóbrega. O Estatuto da Cidade, capturado na internet em agosto/01 http://www.bpdir.adv.br/artigos_005.htm

NOGUEIRA, Ruy Barbosa. Curso de Direito Tributário. 9. ed. São Paulo: Saraiva, 1989.

OLIVEIRA, José Marcos Domingues de. Capacidade Contributiva Conteúdo e eficácia do princípio. Rio de Janeiro: Renovar, 1988.

OLIVEIRA, Yone Dolácio de. A Progressividade do IPTU, in Repertório IOB de jurisprudência, $\mathrm{n}^{\mathrm{a}} 23 / 90$, págs. 377/379.

OLIVEIRA, Yonne Dolacio de. Progressividade do IPTU e princípios da capacidade contributiva e da redistribuição. Cadernos de Direito Tributário e Finanças Públicas, São Paulo, v. 5, n. 17, out./dez. 1996.

PAIVA, João Pedro Lamana Paiva e Burtet, Tiago Machado. Breves Comentários ao Estatuto da Cidade. In caderno de Direito Municipal, Interesse Público 12-2001;

SAULE JÚNIOR, Nelson. O tratamento constitucional do plano diretor como instrumento de política urbana in Direito Urbanístico (Org. Edésio Fernandes), Belo Horizonte: Del Rey, 1998.

SCARCIOFFOLO, Aurélia Sampere. Imposto Predial e Territorial Urbano. Revista de Direito Tributário, v. 51. 
SILVA, Orlan Fábio da. IPTU progressivo, aplicabilidade e emenda constitucional $n^{\underline{a}}$ 29. In: Jus Navigandi, n. 48. [Internet] http:// www1.jus.com.br/doutrina/texto.asp?id=1394. Capturado 03.Ago.2002.

SILVA, José Afonso da. Curso de Direito Constitucional Positivo. $6^{\circ}$ ed., SP, RT.

SOUZA, Carlos Renato Silva e. Capacidade contributiva, IPTU e progressividade. Revista de Direito Tributário, São Paulo, n. 76, p. 243-268. 1997.

TONIN, Helaine Geraldi Goraib. Progressividade no IPTU. Cadernos de Direito Tributário e Finanças Públicas, São Paulo, v. 5, n. 20, p. 89-109, jul./ set. 1997.

URBANO, Fábio Henrique de Araújo. IPTU progressivo. Aplicação para fins de garantia da função social da propriedade. In: Jus Navigandi, n. 23. [Internet] http://wwwl.jus.com.br/doutrina/texto.asp?id=1391. Capturado 03.Ago.2002.

Artigo publicado originariamente na Coletânea sobre IPTU editado pela Editora Quartier Latin, SP, 2002 sob a coordenação de Marcelo Guimarães Peixoto. 